\title{
PERILAKU INDIVIDU DALAM LEMBAGA PENDIDIKAN ISLAM
}

\author{
Khoirunnisaa', Sulistiyorini \\ (STAI Madiun, IAIN Tulungagung) \\ khoirunnisaa729@gmail.com, sulistyorini12@yahoo.com
}

\section{Abstract}

The study of aspects of human behavior in a particular group which includes aspects caused by the influence of organizations on humans as well as human influences on organizations including organizational behavior. There are two factors that influence individual behavior towards Islamic educational institutions, namely internal and external factors. Internal factors include heredity (heredity or innate). External factors include the environment, maturity or experience and education. While the individual behavior analysis variables include psychological, physiological and environmental variables. Psychological variables include perceptions, personality attitudes, learning and motivation. Physiological variables include physical abilities and mental abilities. And environmental variables include family, culture and social class. As an initial understanding to be able to understand individual behavior well, it is necessary to understand the characteristics inherent in individuals which include biographical characteristics, personality, perceptions and attitudes. The verses of the Qur'an relating to individual behavior form the basis that Islamic educational institutions have hinted that humans have positive and negative potentials in behavior, and in essence the positive potential of humans is stronger than their negative potential.

Keywords: Behavior, individual, individual behavior, Islamic educational institutions, organizations 


\section{Abstrak}

Studi tentang aspek-aspek tingkah laku manusia dalam suatu kelompok tertentu yang meliputi aspek yang ditimbulkan oleh pengaruh organisasi terhadap manusia begitu juga pengaruh manusia terhadap organisasi termasuk dalam perilaku organisasi. Terdapat dua faktor yang mempengaruhi perilaku individu terhadap lembaga pendidikan Islam yaitu faktorinternal dan eksternal. Faktor internal meliputi Hereditas (keturunan atau bawaan). Faktor eksternal melipuiti lingkungan, kematangan atau pengalaman dan pendidikan. Sedangkan variabel analisis perilaku individu meliputi variabel psikologis, fisiologis dan lingkungan. Variabel psikologis meliputi persepsii, sikap kepribadian, belajar dan motivasi. Variabel fisiologis meliputi kemampuan fisik dan kemampuan mental. Dan Variabel lingkungan meliputi keluarga, kebudayaan dan kelas sosial. Sebagai pemahaman awal untuk dapat memahami perilaku individu dengan baik maka perlu adanya pemahaman karakteristik yang melekat pada individu yang meliputi ciri - ciri biografis, kepribadian, persepsi dan sikap. Ayat-ayat Al-Qur'an yang berkaitan dengan perilaku individu menjadi dasar bahwa dalam lembaga pendidikan Islam sudah diisyaratkan bahwa manusia memiliki potensi positif dan negatif dalam berperilaku, dan pada hakikatnya potensi positif manusia lebih kuat daripada potensi negatifnya.

Kata kunci: Perilaku, individu, perilaku individu, lembaga pendidikan Islam, organisasi

\section{PENDAHULUAN}

Ilmu perilaku organisasi tidak hanya dibahas dan dimanfaatkan dalam kegiatan usaha industri yang menghasilkan sebuah produk, tetapi juga bergerak dalam bidang pendidikan. Demikian halnya di bidang pendidikan Islam, teori-teori organisasi turut dibutuhkan untuk mewujudkan lembaga pendidikan yang lebih profesional dan berkualitas.

Perilaku organisasi (organizational behavior) sebagai sebuah bidang studi yang konsen pada permasalahan yang dipengaruhi oleh individu, kelompok, dan struktur terhadap perilaku dalam organisasi, yang bertujuan menerapkan ilmu pengetahuan untuk meningkatkan efektifitas sebuah organisasi atau lembaga pendidikan. ${ }^{1}$ Selain itu dalam perilaku organisasi

${ }^{1}$ Khairul Maulana, Resume Perilaku Organisasi, (Makalah Sekolah Tinggi Manajemen Informatika dan Komputer STMIK Mercusuar, 2010), h. 7. 
terjadi interaksi dan hubungan antara organisasi di satu pihak dan perilaku individu lain. ${ }^{2}$

Studi tentang aspek-aspek tingkah laku manusia dalam suatu kelompok tertentu yang meliputi aspek yang ditimbulkan oleh pengaruh organisasi terhadap manusia begitu juga pengaruh manusia terhadap organisasi termasuk dalam perilaku organisasi. Hal ini bertujuan untuk sebuah usaha yang mendeterminasi pengaruh manusia terhadap pencapaian tujuan-tujuan organisasi. $^{3}$

Pembahasan tentang perilaku organisasi, saat ini telah berkembang bersamaan dengan perkembangan kegiatan manusia dalam organisasi. Perilaku organisasi sangat penting untuk dipelajari, karena perilaku individu manusia dalam sebuah organisasi akan berpengaruh secara langsung maupun tidak langsung terhadap organisasi dalam mencapai suatu tujuan.

Pada tulisan ini terdapat konteks ilmu tentang psikologi, sosial dan agama. Yang berhubungan dengan psikologi adalah kelimuan yang berkaitan tentang perilaku, yang berkaitan dengan sosial yaitu lembaga pendidikan yang menjadi wadah atau tempat berkumpulnya individu untuk melakukan aktivitas dan interaksi. Sedangkan agama disini karena lembaga pendidikan Islam tentunya aktivitas yang dilakukan dilandasi dengan ajaran-ajaran agama Islam.

Berdasarkan hal tersebut maka artikel yang sederhana ini berfokus pada pembahasan perilaku individu dalam lembaga pendidikan Islam yang meliputi tentang konsep dasar perilaku individu, faktor-faktor yang mempengaruhi perilaku individu, variabel-variabel analisa perilaku individu dan perilaku individu dalam lembaga pendidikan Islam serta implementasinya dalam lembaga pendidikan Islam

\section{PERILAKU INDIVIDU}

\section{Konsep Dasar Perilaku}

Perilaku merupakan sebuah tindakan yang di dalamnya terdapat aktivitas manusia yang membutuhkan berbagai tindakan. Cakupan pengertiannya pun sangat luas, dalam hal ini akan berkaitan dengan cara seseorang tertawa, bekerja dan juga berjalan. Sehingga adanya perilaku kehidupan

2 Fitriani Perilaku, Organisasi dan Kepemimpinan Sebagai Sebuah Sistem, Jurnal IAIN Bone 2018

3 Rivai Veitzhal \& Deddy Mulyadi. Kepemimpinan dan Perilaku Organisasi, Jakarta: RajaGrafindo Persada, 2011, h. 170 
manusia akan berkaitan dengan aktivitas manusia itu sendiri.

Untuk pengertian dari perilaku sendiri memang perlu dibatasi dengan adanya sebuah keadaan jiwa yang bisa membuat seseorang lebih mudah dalam berfikir dan juga berpendapat. Dalam psikologi, teori perilaku dapat diumpamakan dari berbagai suatu reaksi yang bisa berkaitan atau berhubungan dengan sebuah reaksi lingkungan.

Skinner dalam Notoatmodjo ${ }^{4}$ berpendapat bahwa dalam perumusan sebuah tingkah laku dapat dilakukan dengan berbagai respon dan juga reaksi yang bisa diperoleh dari adanya stimulus atau rangsangan dari luar. Perilaku yang satu ini malalui proses adanya stimulus terhadap organisme, dan kemudian organisme tersebut merespon sehingga dalam teori skinner disebut dengan teorii "S-0-R" atau sebuah Stimulus - Organisme- Respon.

Ensiklopedi Amerika, dalam hal ini dikemukakan oleh Roberts Y.Kwick menyatakan bahwa perilaku dapat diartikan sebagai suatu aksi yang di dalamnya terdapat reaksi organisme terhadap lingkungan, dalam hal ini juga berarti adanya sebuah perilaku baru yang akan terwujud bila ada sesuatu tanggapan atau rangsangan dengan demikian maka suatu rangsangan tertentu juga dapat menghasilkan sebuah perilaku tertentu.

Petty cocopio mengatakan bahwa perilaku merupakan sebuah evaluasi umum yang dibuat oleh manusia terhadap dirinya sendiri dan juga melalui obyek atau sebuah issue yang telah dilakukan.

Perilaku menurut Chief, Bogardus, Lapiere dan Gordon allport yaitu terdapat kelompok pemikiran dan juga sikap yang merupakan sebuah ancaman dari kesiapan dalam melakukan reaksi pada suatu objek dengan cara - cara tertentu. Dengan adanya kesiapan yang dimaksudkan dalam hal ini merupakan kecenderungan yang potensial untuk bereaksi dengan cara tertentu apabila individu dihadapkan pada suatu stimulus yang menghendaki adanya sebuah respon yang dilakukan.

Fredrick Herzberg mengatakan bahwa sama halnya seperti teori yang telah diungkapkan oleh maslow, herzbeg dalam studinya juga mengembangkan konsep- konsep motivasi yang merupakan penentu utama dari munculnya motivasi yaitu sebuah kondisi tempat kerja, upah kualitas pengawasan dan juga pengakuan, promosi dan juga peningkatan profesionalisme.

Elton Mayo dalam studi hawthrne di western electric company 19271932. merupakan munculnya dari sebuah perilaku dalam organisasi. Mayo

${ }^{4}$ Notoatmodjo, Soekidjo. Pendidikan dan Perilaku Kesehatan, Jakarta: Rineka Cipta, 2003, h. 37 
adalah seoorang psikolog dari Harvard university yang memandu penelitian tentang rancang ulang pekerjaan, perubahan panjang hari kerja dan juga waktu kerja dalam seminggu. Pengenalan waktu untuk istirahat kerja dan juga upah dari individu yang dibandingkan dengan sebuah upah kelompok.

\section{Perilaku Individu}

Seorang pemimpin atau manajer dalam mengelola organisasi harus memahami perilaku individu sebagai landasan untuk mengelola orangorang yang ada di dalamnya. Masalah perilaku individu merupakan salah satu masalah yang amat pelik yang selalu dihadapi oleh semua manager berbagai organisasi, yang oleh karena itu perlu sekali dipelajari dan dipahami agar tujuan organisasi dapat dicapai secara efektif dan efisien. ${ }^{5}$

Pola-pola perilaku manusia mengalami perubahan walau sedikit. Dan setiap manajer sudah tentu berkeinginan untuk menimbulkan perubahan dalam perilaku, yang dapat menyebabkan makin membaiknya performa para karyawan mereka. Perilaku manusia terlampau kompleks untuk diterangkan oleh sebuah generalisasi yang dapat diterapkan terhadap sesama manusia. ${ }^{6}$

Sedangkan perilaku individu merupakan bagian dari pembahasan perilaku organisasi. Menurut Miftah Thoha perilaku organisasi pada hakikatnya adalah hasil-hasil interaksi antara individu-individu dalam organisasinya, maka untuk mengetahui perilaku organisasi dengan baik terlebih dahulu yang harus diketahui adalah perilaku individu-individu yang ada dalam organisasi.

Perilaku menurut Miftah Thoha adalah suatu fungsi dari interaksi antara seseorang dengan lingkungannya, sedangkan perilaku individu adalah fungsi dari interaksi antara person atau individu dengan lingkungannya. ${ }^{7}$

\section{Faktor-Faktor yang Mempengaruhi Perkembangan Individu}

Faktor-faktor yang mempengaruhi perkembangan individu ada 2 yaitu faktor internal dan faktor eksternal yang antara lain:

\footnotetext{
5 Sopiah, Perilaku Organisasional, (Yogyakarta: CV Andi Offset, 2008), h. 24.

6 J. Winardi, Manajemen Perilaku Organisasi, (Jakarta: Kencana Prenada Media Group, 2004), h. 198.

7 Arrafiqur Rahman, Pengaruh Perilaku Individu Terhadap Kinerja Pegawai Pada Kantor Wilayah Departemen Agama Provinsi RI, Jurnal Ilmiah Cano Ekonomos Vol.2.No.1 Januari 2013
} 
Faktor internal, yang termasuk dalam faktor internal yaitu Hereditas (keturunan atau bawaan) menurut ahli yang beraliran nativisme mengatakan bahwa faktor yang mempengaruhi individu semata-mata di tentukan oleh unsur pembawaan. faktor pembawaan adalah proses penurunan sifat-sifat atau ciri-ciri tertentu yang ada pada orang tua atau dari keturunan kerabatkerabat terdekat. sifat bawaan ini sulit untuk dirubah udah menjadi kebiasaan atau keturunan dari sifat orang tuanya.

Pada dasarnya yang diturunkan oleh orang tua merupakan bentuk atau struktur tubuh pada anak-anak tersebut yang merupakan hasil dari percampuran gen-gen dari orang tua yang pada umumnya mencakup sifat, ciri-ciri atau sifat dari orang tua yang di peroleh dari lingkungan atau dari hasil belajar didalam lingkungan tersebut.

Seperti misalnya Seorang anak terbiasa berjalan tegak atau menunduk, terbiasa atau cenderung untuk menjadi orang lincah, pendiam, cerewet dan sebagainya.

Ini merupakan contoh dari kebiasaan atau sifat-sifat yang diturunkan oleh orang tua kepada anaknya. kebiasaan ini tidak hanya terdapat selama masa kanak-kanak, melainkan tetap ada pada diri manusia selama masih hidup.

Akan tetapi kebiasaan-kebiasaan ini tidak akan menjadi kenyataan kecuali kita tidak mendapatkan respon atau kesemptan kita untuk berkembang atau merubah sifat-sifat ini.

Faktor eksternal, Kondisi lingkungan. menurut ahli aliran empirisme berpendapat bahwa perkembangan individu sepenuhnya ditentukan oleh faktor lingkungan/pendidikan. Faktor atau kondisi lingkungan ini juga mempengaruhi perkembangan manusia. Lingkungan merupakan suatu tempat dimana kita saling membutuhkan atau saling berinteraksi antara manusia yang satu dengan manusia yang lain.

Lingkungan sebagai penentu perkembangan tingkah laku manusia, didalam dugaan yang diterima sebagai dasar didalam lingkungan psikologis adalah bahwa manusia lahir dalam keadaan tidak memiliki pembawaan apapun, bagaikan kertas putih (tabula rasa) yang dapat ditulisi dengan apa saja yang kita kehendaki.

Perwujudan tingkah laku manusia ditentukan oleh lingkungan dengan kiat-kiat rekayasa yang bersifat pribadi atau tidak berkaitan dengan seseorang dan bersifat direktif.

Bayi yang lahir mempunyai kecenderungan yang sama, didalam pengaruh faktor lingkungan kita bisa mengambil contoh kepada bayi yang 
menyusu, ketika bayi menyusu bayi tersebut merasa senang dan ketika bayi merasa haus maka bayi tersebut menangis maka dengan cepat seorang ibu memberkan ASI. Yang dimaksud dengan faktor lingkungan disini adalah lingkungan keluarga.

Lingkungan keluarga ini sangat mempengaruhi perkembangan manusia. Keluarga merupakan lingkungan atau kelompok yang pertama yang menjadi pusat identifikasi anak dan kelompok atau lingkungan yang pertama mengenalkan nilai-nilai kehidupan kepada anak, anak menghabiskan masa kanakkanaknya itu didalam lingkungan keluarga.

Maturation (kematangan). Kematangan adalah siapnya suatu organorgan fungsi kehidupan, baik pisik maupun psychis untuk berkembang dan melakukan tugasnya dengan baik.

Bagaimanapun banyaknya pembawaan atau kebiasaan seseorang individu dan betapapun baiknya lingkungan yang tersedia baginya bila belum mencapai kematangan untuk berfungsi maka suatu fungsi kehidupan belum dapat berkembang secara optional.

Pembawaan dan lingkungan adalah faktor-faktor yang sangat penting bagi perkembangan individu. Interaksi antara faktor-faktor tersebut tidak terjadi sekehendak hati, tapi dipengaruhi oleh faktor yang ketiga ini yaitu faktor kematangan (maturation) atau waktu (time).

Manusia yang baru dilahirkan telah memiliki bakat dan pembawaan, baik dari lingkungan berasal dari keturunan orang tuanya, nenek moyangnya maupun karena memang ditakdirkan demikian.

Faktor Maturation (kematangan) merupakan foktor dimana semua organ tubuh siap menjalankan fungsinya masing-masing.

Jadi perkembangan manusia dapat dipengaruhi oleh berbagai macam faktor-faktor seperti yang telah disebutkan dan di jelaskan diatas.

Faktor-faktor ini dapat mempengaruhi perkembangan manusia mulai sejak lahir sampai meninggal dalam mempengaruhi ke arah yang lebih baik maupun yang tidak baik.

Pendidikan. Secara luas pendidikan mencakup seluruh proses kehidupan individu sejak dalam ayunan hingga liang lahat, berupa interaksi individu dengan lingkungannya, baik secara formal maupun informal. Proses dan kegiatan pendidikan pada dasarnya melibatkan masalah perilaku individu maupun kelompok. 


\section{Variabel-Variabel Analisis Perilaku Individu}

Gibson dkk., berpendapat bahwa kerangka kerja dalam menganalisis perilaku individual memerlukan pertimbangan tentang tipe-tipe variabel seperti variabel psikologis, fisiologis dan variabel lingkungan. Variabel psikologis meliputi persepsii, sikap kepribadian, belajar dan motivasi. Variabel fisiologis meliputi kemampuan fisik dan kemampuan mental. Dan Variabel lingkungan meliputi keluarga, kebudayaan dan kelas sosial.

Sebagai pemahaman awal supaya dapat memahami perilaku individu dengan baik maka terlebih dahulu kita harus memahami karakteristik yang melekat pada individu. Adapun karakteristik yang melekat pada individu tersebut antara lain: ciri - ciri biografis, kepribadian, persepsi dan sikap. ${ }^{8}$

Karakteristik Biografis yaitu karakteristik yang berhubungan dengan pribadi seperti umur, jenis kelamin, dan status kawin dan masa kerja. ${ }^{9}$ Kemampuan yaitu kapasitas individu untuk mengerjakan berbagai tugas dalam suatu pekerjaan. Kemampuan intelektual, merupakan kemampuan yang yang diperlukan untuk mengerjakan kegiatan mental. Misalnya: berpikir, menganalisis, dan memahami. yang mana dapat diukur dalam bentuk tes (tes IQ). Dan setiap orang punya kemampuan yang berbeda. Kemampuan fisik, merupakan kemampuan yang diperlukan untuk melakukan tugas yang menuntut stamina, kecekatan dan kekuatan.

Kepribadian, Dalam banyak buku disebutkan bahwa kepribadian ditentukan oleh faktor keturunan, lingkungan dan ditambah berbagai faktor situasional. Maksudnya, kepribadian seseorang banyak ditentukan oleh faktor keturunan dan lingkungan yang relatif stabil itu dapat berubah karena situasi dan kondisi yang berubah. Tipe kepribadian menurut John Holland yaitu bahwa penting membangun keterkaitan atau kecocokan antara tipe kepribadian individu dan pemilihan karir tertentu.

Adapun karakteristik kepribadian yang populer diantaranya adalah agresif, malu, pasrah, malas, ambisius, setia, jujur. Semakin konsisten karakteristek tersebut muncul di saat merespons lingkungan, hal itu menunjukkan faktor keturunan atau pembawaan (traits) merupakan faktor yang penting dalam membentuk kepribadian seseorang. ${ }^{10}$

Persepsi, Menurut David Krech cs., peta kognitif seorang individu,

8 Sopiah, Perilaku Organisasional, (Yogyakarta: CV Andi Offset, 2008), h. 13.

9 Robbins Stephen. Perilaku Organisasional. Jakarta: INDEK Kelompok GRAMEDIA. 2003, h. 46

${ }^{10}$ Sopiah, Perilaku Organisasional, (Yogyakarta: CV Andi Offset, 2008), h. 15. 
bukanlah sebuah pencerminan fotgrafis dari dunia fisikal, tetapi, ia lebih merupakan konstruksi pribadi, dimana objek-objek tertentu, yang diseleksi oleh individu tersebut untuk peranan penting tertentu, dipersepsi olehnya dengan cara individual.

Oleh karenanya setiap pihak yang menerima persepsi, hingga tingkat tertentu dapat kita analogikan dengan seorang pelukis, yang melukis sebuah gambar tentang dunia, yang mengekspresi pandangan individualnya tentang kenyataan. ${ }^{11}$

Gitosudarmo, I. menyebutkan bahwa persepsi sebagai suatu proses memperhatikan dan menyeleksi, mengorganisasikan dan menafsirkan stimulus lingkungan. Memahami persepsi individu ataupun kelompok merupakan sesuatu hal yang penting sebab dalam kehidupan seharihari, baik di organisasi maupun di masyarakat umum, perilaku individu/ kelompok dituntun atau didasari oleh bagaimana dia mempersepsikan semua stimulus yang datang dari lingkungan, yang kadang-kadang bahkan persepsi seseorang/kelompok tersebut seringkali sama sekali tidak menunjukkan situasi dan kondisi yang sebenarnya. Perbedaan persepsi tiap individu/kelompok dalam memaknai suatu tugas, misalnya di organisasi, adalah hal biasa. Dampaknya adalah timbulnya permasalahan atau bahkan konflik antarindividu maupun antarkelompok. Oleh karena itu memahami persepsi baik individu maupun kelompok amatlah penting ${ }^{12}$

Sikap, Sikap adalah pernyataan atau pertimbangan evaluatif (menguntungkan atau tidak menguntungkan) mengenai objek, orang dan peristiwa. Sikap mencerminkan bagaimana seseorang merasakan mengenai sesuatu. Dalam perilaku organisasi, pemahaman atas sikap penting, karena sikap mempengaruhi perilaku kerja.

Sebuah sikap merupakan suatu keadaan siap mental, yang dipelajari dan diorganisasi menurut pengalaman, dan yang menyebabkan timbulnya pengaruh khusus atas reaksi seseorang terhadap orang-orang, objek-objek, dan situasi-situasi dengan siapa ia berhubungan. ${ }^{13}$

Al-Qur'an juga mengisyaratkan bahwa manusia berpotensi positif dan negatif, pada hakikatnya potensi positif manusia lebih kuat dari-

\footnotetext{
${ }^{11}$ J. Winardii, Manajemen Perilaku Organisasi, (Jakarta: Kencana Prenada Media Group, 2004), h. 204.

${ }^{12}$ Sopiah, Perilaku Organisasional, (Yogyakarta: CV Andi Offset, 2008), h. 18 - 19.

${ }^{13}$ J. Winardii, Mnajemen Perilaku Organisasi, (Jakarta: Kencana Prenada Media Group, 2004), h. 211.
} 
pada potensi negatifnya. Hanya saja daya tarik keburukan lebih kuat dibanding daya tarik kebaikan. Potensi positif dan negatif manusia ini banyak diungkap oleh Al-Qur'an. Di antaranya ada dua ayat yang menyebutkan potensi positif manusia, yaitu Surah at-Tin (95) ayat 4 yang artinya:" Sesungguhnya Kami telah menciptakan manusia dalam bentuk yang sebaik-baiknya." Jadi manusia diciptakan dalam bentuk dan keadaan yang sebaik-baiknya. dan Surah al-Isra' (7) ayat 70 yang artinya:". Dan sesungguhnya telah Kami muliakan anak-anak Adam, Kami angkut mereka di daratan dan di lautan, Kami beri mereka rezki dari yang baik-baik dan Kami lebihkan mereka dengan kelebihan yang sempurna atas kebanyakan makhluk yang telah Kami ciptakan." Manusia dimuliakan oleh Allah dibandingkan dengan kebanyakan makhluk-makhluk yang lain).

Ayat Al-Qur'an yang mencela manusia dan memberikan cap negatif terhadap manusia diantaranya adalah manusia amat aniaya serta mengingkari nikmat dalam Surat Ibrahim (14): 34 yang artinya:" Dan Dia telah memberikan kepadamu (keperluanmu) dan segala apa yang kamu mohonkan kepadanya. dan jika kamu menghitung nikmat Allah, tidaklah dapat kamu menghinggakannya. Sesungguhnya manusia itu, sangat zalim dan sangat mengingkari (nikmat Allah)." Lalu ayat tentang manusia sangat banyak membantah dalam Surat Al-Kahfi (18): 54. yang artinya:" Dan yang Sesungguhnya Kami telah mengulang-ulangi bagi manusia dalam Al Quran ini bermacam-macam perumpamaan. dan manusia adalah makhluk yang paling banyak membantah." Dan manusia bersifat keluh kesah lagi kikir terdapat dalam Surat Al-Ma'arij (70): 19 yang artinya: "Sesungguhnya manusia diciptakan bersifat keluh kesah lagi kikir."

Sebenarnya, dua potensi manusia yang saling bertolak belakang ini diakibatkan oleh persatruan di antara tiga macam nafsu, yaitu nafsu ammarah bi as-suu'(jiwa yang selalu menyuruh kepada keburukan), dlam Surat Yusuf (12) ayat 53 yang artinya:" Dan aku tidak membebaskan diriku (dari kesalahan), karena Sesungguhnya nafsu itu selalu menyuruh kepada kejahatan, kecuali nafsu yang diberi rahmat oleh Tuhanku. Sesungguhnya Tuhanku Maha Pengampun lagi Maha Penyanyang." nafsu lawwamah (jiwa yang amat mencela), terdapat dalam Surat al-Qiyamah (75) ayat 1-2 yang artinya:" Aku bersumpah demi hari kiamat(1) Dan aku bersumpah dengan jiwa yang Amat menyesali (dirinya sendiri) (2) Maksudnya: bila ia berbuat kebaikan ia juga menyesal kenapa ia tidak berbuat lebih banyak, apalagi kalau ia berbuat kejahatan. Dan nafsu muthma’innah (jiwa yang tenteram), terdapat 
dalam Surat al-Fajr (89) ayat 27-30 yang artinya:" Hai jiwa yang tenang (27). Kembalilah kepada Tuhanmu dengan hati yang puas lagi diridhai-Nya. (28) Maka masuklah ke dalam jama'ah hamba-hamba-Ku (29) masuklah ke dalam syurga-Ku(30)

Konsepsi dari ketiga nafsu tersebut merupakan beberapa kondisi yang berbeda yang menjadi sifat suatu jiwa di tengah-tengah pergulatan psikologis antara aspek material dan aspek spiritual. ${ }^{14}$

\section{LEMBAGA PENDIDIKAN ISLAM}

Dalam kamus bahasa Indonesia, pengertian lembaga ialah badan (organisasi) yang tujuannya melakukan sebuah penyelidikan keilmuan atau melakukan suatu usaha ${ }^{15}$. Menurut ensiklopedi Indonesia, lembaga pendidikan yaitu suatu wadah pendidikan yang dikelola demi mencapai hasil pendidikan yang diinginkan. Badan pendidikan sesungguhnya termasuk pula dalam alat - alat pendidikan, jadi badan/lembaga pendidikan yaitu organisasi atau kelompok manusia yang karena sesuatu dan lain hal memikul tanggung jawab atas terlaksananya pendidikan agar proses pendidikan dapat berjalan dengan wajar. Secara terminologi lembaga pendidikan Islam adalah suatu wadah, atau tempat berlangsungnya proses pendidikan Islam, lembaga pendidikan itu mengandung konkirit berupa sarana dan prasarana dan juga pengertian yang abstrak, dengan adanya norma-norma dan peraturan-peraturan tertentu, serta penanggung jawab pendidikan itu sendiri. ${ }^{16}$

Lembaga pendidikan Islam adalah suatu wadah atau tempat berlangsungnya proses pendidikan Islam. Baik berupa sarana pra sarana dan adanya norma-norma dan peraturan-peraturan tertentu, serta mengajarkan ilmu pengatahuan.

Lembaga pendidikan mempunyai karakteristik tersendiri sesuai dengan core value yang dikembangkannya. Nilai-nilai inti yang menjadi ajaran Islam inilah yang akan mewarnai proses pengelolaan dan penyelenggaraan pendidikan Islam. Perilaku manajerial dalam mengelola lembaga pendidikan Islam harus senantiasa didasarkan pada ajaran-ajaran Islam yang bersumber

${ }^{14}$ Suparlan, Psikologi Dan Kepribadian Perspektif Al-Quran, Humanika Vol. 8 No. 1 2008, lihat juga Aat Hidayat, Psikologi Dan Kepribadian Manusia: Perspektif Al Qur'an Dan Pendidikan Islam, Jurnal Penelitian,Vol. 11, No. 2, Agustus 2017

${ }^{15}$ Desi Anwar, Kamus Bahasa Indonesia Modern, Surabaya: Amelia, 2002, h, 219

${ }^{16}$ Mardiah, Konsep Dasar Manajemen Lembaga Pendidikan Islam, Jurnal ZIRAH Vol. 1, No. 1, September 2019 
dari al-Quran dan al-Hadis serta praktik-praktik keteladanan yang diberikan oleh para ulama dan pemimpin Islam. ${ }^{17}$

\section{PERILAKU INDIVIDU DALAM LEMBAGA PENDIDIKAN ISLAM}

Pengelolaan organisasi, dalam hal ini lembaga pendidikan Islam, seorang pemimpin atau manajer harus memahami karakteristik atau perilaku individu sebagai landasan untuk mengelola orang-orang yang ada dalam lembaga tersebut. Masalah perilaku individu merupakan salah satu masalah yang amat pelik yang dihadapi oleh semua manajer berbagai organisasi atau lembaga pendidikan Islam, yang oleh karena itu perlu sekali dipelajari dan dipahami agar tujuan organisasi dapat dicapai secara efektif dan efisien. ${ }^{18}$

Pola-pola perilaku manusia senantiasa mengalami perubahan, walupun sedikit. Dan setiap manajer sudah tentu berkeinginan untuk membuat perubahan dalam perilaku, yang dapat berdampak makin membaiknya performa para karyawan mereka. Perilaku manusia terlampau kompleks untuk diterangkan oleh sebuah generalisasi yang dapat diterapkan terhadap sesama manusia. ${ }^{19}$

Untuk dapat menganalisa perilaku individu dalam lembaga pendidikan maka perlu diuraikan keterkaitan variabe-variabel yang berhubungan denga perilaku individu dan lembaga pendidikan yang antara lain variabel dasar perilaku yang meliputi:

Karakteristik Biografis yang terdiri dari umur, umur individu pada masa ini termasuk pada golongan dewasa, kriteria untuk masa dewasa yaitu kemandirian ekonomi dan kemandirian dalam mengambil keputusan. ${ }^{20}$ Untuk Jenis kelamin yang dimaksudkan disini adalah laki-laki dan perempuan, status perkawinan yaitu sudah kawin dan belum kawin, untuk masa kerja tentunya termasuk individu yang sudah bekerja karena menjadi bagian dari sebuah lembaga sebagai sumberdaya manusia yang melakukan aktivitas pada lembaga pendidikan.

${ }^{17}$ Prim Masrokan Mutohar, Manajemen Mutu Sekolah, Yogyakarta: Ar-Ruzz Media, 2013, h. 29

${ }^{18}$ Sopiah, Perilaku Organisasional, (Yogyakarta: CV Andi Offset, 2008), h. 24.

${ }^{19}$ J. Winardi, Manajemen Perilaku Organisasi, (Jakarta: Kencana Prenada Media Group, 2004), h. 198.

${ }^{20}$ John. W. Santrock, Live-Span Development, Perkembangan Masa Hidup, Edisi 5 Jilid II, Jakarta: PENERBIT ERLANGGA, 1995, h. 90 
Kemampuan yang dimaksudkan disini adalah pertama, kemampuan intelektual atau kognitif, yaitu kemampuan untuk melakukan aktivitas yang mengandalkan analisis logis. Dalam lembaga pendidikan Islam kemampuan kognitif berpikir kritis ini ini dicontohkan individu yang mampu memberikan sumbangan pemikiran untuk mengembangkan segala aspek yang berkaitan dengan lembaga, misalnya supaya lembaga tersebut menjadi lembaga pilihan dari peserta didik atau wali murid maka harus mampu memberikan pelayanan yang bermutu, yaitu menyediakan SDM yang unggul untuk mendidik peserta didik. Kedua, kemampuan fisik, yaitu kemampuan kekuatan atau ketrampilan untuk melakukan aktivitas yang membutuhkan stamina. Individu yang memiliki stamina dan cekatan sangat dibutuhkan untuk merespon masalah-masalah yang berkaitan dengan pengembangan lembaga pendidikan, misalnya ketrampilan individu untuk memanfaatkan media pembelajaran untuk peningkatan prestasi peserta didik.

Kepribadian, merupakan faktor keturunan dan lingkungan bisa berubah karena kondisi dan situasi dan ditambah dari faktor situasional. Sedangkan karakteristik kepribadian individu yang agresif dalam lembaga pendidikan Islam lebih pada respon cepat terhadap situasi dan kondisi yang ada, misalnya memberikan usulan kegiatan tambahan untuk menunjang prestasi peserta didik. untuk individu yang pemalu cenderung tidak mengungkapkan pemikirannya secara langsung, pasrah adalah individu yang menerima apapun yang di perintahkan oleh atasannya, atau kepala madrasah. malas, ambisius, setia, jujur.. Semakin konsisten karakteristik tersebut muncul di saat merespon lingkungan. Hal itu menunjukkan faktor keturunan atau pembawaan (traits) merupakan faktor yang penting dalam membentuk kepribadian seseorang. Teori tipe kepribadian adalah pandangan ahli teori teori pekerjaan John Holland yaitu bahwa penting membangun keterkaitan atau kecocokan antara tipe kepribadian individu dan pemilihan karir tertentu. Holand mengajukan enam tipe kepribadian dasar yang berhubungan sengan karir yaitu realistik, investigatif, artistik, sosial, wiraswasta, dan konvensional. ${ }^{21}$

Pada masa dewasa awal sebagian besar individu memasuki beberapa tipe pekerjaan. Orang dewasa muda tidak sistematis dan tidak memiliki arah alam eksplorasi dan perencanaan karir mereka, sehingga mereka mugah sekali berubah. Siklus pekerjaan memiliki empat fase utama: seleksi dan masuk kerja, penyesuaian diri, pemeliharaan, dan pensiun.

${ }^{21}$ Hendri Selanno, Faktor Internal yang Mempengaruhi Perilaku Organisasi, Populis, Volume 8 No.2 Oktober 2014, h. 44-56 


\section{KESIMPULAN}

Perilaku pada dasarnya berorientasi pada tujuan (goal oriented), dengan kata lain perilaku pada umumnya dimotivasi oleh suatu keinginan untuk mencapai tujuan. Perilaku merupakan semua tindakan yang dilakukan seseorang atau cara bertindak yang menunjukkan tingkah laku seseorang dan tindakan-tindakan tersebut dapat diamati

Dua faktor yang mempengaruhi perilaku individu terhadap lembaga pendidikan Islam yaitu faktor internal dan eksternal. Faktor internal meliputi Hereditas (keturunan atau bawaan). Faktor yang diturunkan oleh orang tua merupakan bentuk atau struktur tubuh pada anak-anak tersebut yang mana hasil dari percampuran gen-gen dari orang tua yang pada umumnya mencakup sifat, ciri-ciri atau sifat dari orang tua yang di peroleh dari lingkungan atau dari hasil belajar didalam lingkungan tersebut. Faktor eksternal melipuiti lingkungan, pengalaman dan pendidikan.

Sedangkan variabel analisis perilaku individu meliputi variabel psikologis meliputi persepsi, sikap kepribadian, belajar dan motivasi., variabel fisiologis meliputi meliputi kemampuan fisik dan kemampuan mental, dan variabel lingkungan meliputi keluarga, kebudayaan dan kelas sosial. Sebagai pemahaman awal untuk dapat memahami perilaku individu dengan baik maka perlu adanya pemahaman karakteristik yang melekat pada individu yang meliputi ciri - ciri biografis, kepribadian, persepsi dan sikap.

Ayat-ayat Al-Qur'an yang berkaitan dengan perilaku individu menjadi dasar bahwa dalam lembaga pendidikan Islam sudah diisyaratkan bahwa manusia memiliki potensi positif dan negatif dalam berperilaku, dan pada hakikatnya potensi positif manusia lebih kuat daripada potensi negatifnya. 


\section{DAFTAR PUSTAKA}

Anwar, Desi. Kamus Bahasa Indonesia Modern. Surabaya: Amelia, 2002.

Baharuddin. Pengembangan Lembaga Pendidikan Islam. Malang: UINMaliki Press, 2011.

Departemen Agama. Al-Quran dan Terjemahan. Bandung: Syamil Qur'an, 2009.

Hidayat, Aat. "Psikologi Dan Kepribadian Manusia: Perspektif Al Qur'an Dan Pendidikan Islam." Jurnal Penelitian 11, no. 2 (Agustus 2017).

Mardiah. "KONSEP DASAR MANAJEMEN LEMBAGA PENDIDIKAN ISLAM." Jurnal ZIRAH 1, no. 1 (September 2019).

Mutohar, Prim Masrokan. Manajemen Mutu Sekolah. Yogyakarta: Ar-Ruzz Media, 2013.

Notoatmodjo, Soekidjo. Pendidikan dan Perilaku Kesehatan. Jakarta: Rineka Cipta, 2013.

Qomar, Mujamil. Manajemen Pendidikan Islam. Malang: PT. Gelora Aksara Pratama, 2012.

Rahman, Arrafiqur. "Pengaruh Perilaku Individu Terhadap Kinerja Pegawai Pada Kantor Wilayah Departemen Agama Provinsi RI." Jurnal Ilmiah Cano Ekonomos 2, no. 1 (Januari 2013).

Santrock, John W. Live -Span Development, Perkembangan Masa Hidup, Edisi 5 Jilid II. Jakarta: PENERBIT ERLANGGA, 1995.

Selanno, Hendri. "Faktor Internal yang Mempengaruhi Perilaku Organisasi." Populis 8, no. 2 (Oktober 2014).

Sopiah. Perilaku Organisasional. Yogyakarta: CV Andi Offset, 2008. Yogyakarta: CV. Andi Offset, 2008.

Stephen, Robbins. Perilaku Organisasi. Jakarta: INDEK Kelompok GRAMEDIA, 2003.

Suparlan. "Psikologi Dan Kepribadian Perspektif Al-Quran." Humanika 8, no. 1 (2008).

Veitzhal, Rivai, and e Deddy Mulyadi. Kepemimpinan dan Perilaku Organisasi. Jakarta: RajaGrafindo Persada, 2011.

Winardi. Manajemen Perilaku Organisasi. Jakarta: Kencana Prenada Media Group, 2004. Jakarta: Kencana Prenada Media Group, 2004. 